\title{
OBITUARY
}

\section{JAMES COLE MARShall}

WE announce with regret the death of Mr. J. Cole Marshall, M.D., F.R.C.S., which occurred suddenly on Christmas Eve at his home in Rickmansworth, Herts.

James Cole Marshall, born in 1876 at Blandford, Dorset, studied at Bart's and qualified in 1900. His first interest was gynaecology, and his M.D. degree, which he took in 1904, a year after taking the Fellowship, was in this subject. Soon afterwards, however, he was attracted to ophthalmology, and decided to make that his specialty.

Although Cole Marshall's main work was done at the Western Ophthalmic Hospital. where he was a member of the honorary staff from 1913 to 1946 and senior surgeon for 11 years, he held other appointments at the Royal Waterloo Hospital, the Lambeth L.C.C. Hospital, and the Northwood and Pinner Hospital. He was further associated with several institutions for the blind, such as the Sunshine Home and the Royal London Society for Teaching and Training the Blind. He was also Oculist to the Royal Academy of Music, and during the first world war he served in the R.A.M.C. as ophthalmic specialist to the Army of the Rhine.

Cole Marshall was an efficient all-round surgeon, skilful, careful, and deliberate as an operator; sound in clinical judgement; and thorough in examination. He was one of the very first in Great Britain to practise the modern operative treatment of retinal detachment, which he continued to study with increasing enthusiasm and practised with remarkable success for the rest of his medical career. This success was primarily due to his careful and prolonged survey of the fundus for retinal tears, etc. These were all systematically plotted on his well-known muscle charts, which are still widely used. His capacity for work and his energy in this and other respects were outstanding, and his methods and example in training a long succession of house-surgeons and registrars were an inspiration to his colleagues. It is no exaggeration to say that he founded a school of detachment surgery at the Western. Although he tried out most of the various techniques, he ultimately remained faithful to puncture diathermy, which he preferred to surface coagulation. In this he was supported by the work of the Weekers in Belgium, who have shown that the puncture technique facilitates the downgrowth of subconjunctival cells, resulting in a firmer scar. He had a craftsman's pride in the quality of his scars, not too weak and not too dense-the latter, owing to scar tissue contraction, predisposing to secondary tears.

In 1935, he gave the Middlemore Lecture at the Birmingham Eye Hospital; in 1938 he was appointed Hunterian professor at the Royal College of Surgeons, and his book "The Operative Technique of Retinal Detachment" was published in the following year.

Cole Marshall was a modest, delightful, and charming personality with a keen sense of humour, interested in music and in painting, and no mean judge of quality in both. He was a well-balanced and lovable person, affectionately admired by patients and colleagues.

In 1905 he married Miss Margaret Compton, who, with their three daughters, survives him. He was singularly fortunate in a happy home life. Between the wars he moved from Albion Street to Rickmansworth, where he built a most attractive house and developed a beautiful and well-timbered garden. The latter was a perennial source of pleasure in that he could there enjoy the twin delights of two favourite hobbies, gardening and bird-watching, but he never lost interest in the affairs of the Western Ophthalmic Hospital, where his death has been felt by all as the personal loss of a friend. 